Review

\title{
Impacts of COVID-19 on a Transitioning Energy System, Society, and International Cooperation
}

\author{
Andrew Chapman * and Takeshi Tsuji \\ International Institute for Carbon Neutral Energy Research, Kyushu University, Fukuoka 819-0395, Japan; \\ tsuji@mine.kyushu-u.ac.jp \\ * Correspondence: chapman@i2cner.kyushu-u.ac.jp; Tel.: +81-09-2802-6878
}

Received: 16 September 2020; Accepted: 3 October 2020; Published: 6 October 2020

\begin{abstract}
Short term outcomes of the COVID-19 pandemic have included improved air quality and reduced carbon dioxide $\left(\mathrm{CO}_{2}\right)$ and other greenhouse gas emissions, while long term repercussions may include a disruption to joint international research efforts, the creation of silos, and the potential for internalizing efforts toward national rather than global goals. In this study, we identified the impacts of reduced mobility on pollutants and emissions, the emergence of nationalist approaches and effects on international cooperation, and how these issues will affect the achievement of global carbon targets and the Sustainable Development Goals (SDGs). COVID-19 presents a global short-term crisis and there is a demonstrated global desire and effort to develop a vaccine and effective treatments. Similarly, climate change is also a near future issue, and as a result we need to reduce $\mathrm{CO}_{2}$ emissions rapidly. This review highlights potential policy interventions, which capitalize on learnings from COVID-19, while identifying SDGs 10,13 and 17 as critical to engendering a successful, cooperative transition toward sustainability. The recognition of the earth as a closed system, demonstrated by the shared impacts of the COVID-19 crisis, may encourage positive future effects on cooperative approaches toward mitigating climate change, another looming crisis for humanity.
\end{abstract}

Keywords: COVID-19; climate change; carbon reduction; energy transition; energy policy; research and development

\section{Introduction}

Since the emergence of the novel human coronavirus disease COVID-19 in December 2019 and the subsequent global pandemic, people around the world have been affected, in terms of health and also in terms of a disruption to societal norms and behavior [1]. As a result of this societal disruption, people's work practices and mobility has been affected, while at the government level, the ability and willingness for cooperation has also been impacted. Short term outcomes have included improved air quality and reduced carbon dioxide $\left(\mathrm{CO}_{2}\right)$ and other greenhouse gas (GHG) emissions, while long term repercussions may include a disruption to joint international research efforts, the creation of silos, and the potential for internalizing efforts toward national rather than global goals.

In spite of the global pandemic, international cooperative efforts such as the Paris Agreements and the Sustainable Development Goals (SDGs), which aim to reduce global GHG emissions [2] and to improve social, economic, and environmental outcomes, are ongoing, with the threat of irreversible climate change remaining for policymakers to address within a closing window of opportunity [3].

COVID-19 has meant that social distancing has become a part of everyday life, whereby people aim to limit their close interaction with others, and often employ physical measures in order to restrict the transmission of the virus, such as wearing masks [4]. These measures have proven effective in limiting the spread of the virus and 'flattening' the curve of infection [5]; however, the fear of viral spread has also meant the enactment of travel restrictions within and between nations around the 
world [6]. Efforts to treat, cure, or provide a vaccine for COVID-19 have proceeded both in isolation (i.e., within a single nation), and cooperatively, across national borders [7], yet fears remain that once a treatment or vaccine is identified, that individual nations will act in their own interest first, not necessarily in the global interest [8].

Similar to the effort to contain and address the threat of COVID-19, the challenges of climate change, and the need for a sustainable low-carbon energy transition are global challenges, requiring cooperative solutions [9]. In addition to the limits placed on collaborative research, including the shift to online collaboration and virtual conferences, the possibility of broader interruptions to scientific collaboration and the prioritization of national over global goals may emerge as a learned behavior from the COVID-19 crisis. Such interruptions will not only delay the global response to climate change but will also exacerbate the issues requiring redress as part of the suite of SDGs. In addition, although we are seeing rapid reductions in atmospheric pollutants and $\mathrm{CO}_{2}$ due to work from home initiatives and travel restrictions, it is not likely that these trends can be sustained as the desire to reinvigorate the economy post-COVID-19 asserts itself [10].

The aim of this research was to identify and describe the impacts of the COVID-19 pandemic on the progress of the low carbon energy transition. These impacts include carbon dioxide reduction and the achievement of relevant SDGs in the future. Further, we aimed to identify policy actions that may ameliorate these impacts and improve progress toward these critical, global goals.

\section{Impacts of COVID-19}

COVID-19 has had a number of impacts on the global community, some of which may have been foreseen, i.e., the increased pressure on hospitals and the necessity for limiting of social interactions. However, there have been several impacts that were not necessarily foreseen or were realized as a result of work-at-home arrangements and the limiting of movement within and across communities. In this study, we focused on three areas relevant to the energy system: 1) the reduction of mobility and resultant reductions in pollutant and GHG emissions, 2) the emergence of nationalist approaches and potential impacts on international cooperation, and 3) how these two issues impact upon the achievement of national and global carbon targets and how this may affect the low-carbon transition of the energy system overall.

\subsection{Reduced Mobility, Aerosols, and GHG Emissions}

Here, we review the reduced mobility and resultant reductions in pollutant and GHG emission in several nations. The first cases of COVID-19 were reported in Wuhan province in China, and as such, China provided the first evidence base for both carbon reductions as a result of reduced mobility, and any rebound effect due to the reopening of the nation following control of the virus' spread. Comparing historical emissions of nitrogen dioxide $\left(\mathrm{NO}_{2}\right)$, sulphur dioxide $\left(\mathrm{SO}_{2}\right)$, carbon monoxide $(\mathrm{CO})$, ozone $\left(\mathrm{O}_{3}\right)$ and particulate matter $\left(\mathrm{PM}_{2.5}, \mathrm{PM}_{10}\right)$, and COVID-19-impacted emissions in 26 provincial capitals of China identified overall reductions in $\mathrm{NO}_{2}$, even taking into account spring festival reductions, which would usually occur at the same time as the COVID-19 outbreak. Satellite measurements impaired the quantification of $\mathrm{SO}_{2}$ and $\mathrm{CO}$ reductions, however ground station analysis from Wuhan confirmed their reduction as a result of COVID-19. This analysis also showed that concentrations of $\mathrm{NO}_{2}, \mathrm{SO}_{2}$, and $\mathrm{PM}$ remained low, while $\mathrm{CO}$ levels increased soon after the initial decline due to COVID-19. As a result, air quality was improved overall, but, likely due to a reduction in $\mathrm{NO}_{2}$ in the air; $\mathrm{O}_{3}$ levels were increased for all 26 provincial capitals [11]. Focusing on nitrogen oxides $\left(\mathrm{NO}_{\mathrm{x}}\right)$, it was confirmed that levels decreased considerably $(\sim 50 \%)$ for most provinces compared to pre-COVID-19 lockdowns, and only moderately rebounded $(\sim 26 \%)$ after back-to-work orders were issued for most eastern Chinese provinces. Wuhan was an exception, where $\mathrm{NO}_{\mathrm{x}}$ levels remained low, even into March 2020 [12]. Considering the impact of reduced mobility, an almost $70 \%$ reduction in human mobility in 44 cities in northern China lead to significant decreases in $\mathrm{SO}_{2}(6.76 \%), \mathrm{PM}_{2.5}$, and $\mathrm{PM}_{10}$ $(5.93 \%$ and $13.66 \%), \mathrm{NO}_{2}(24.67 \%)$ and $\mathrm{CO}(4.58 \%)$, highlighting the flow-on impacts of decreased 
mobility on industrial and commercial activities linked to our daily lives [13]. A broad study across 366 urban areas of China confirmed other results relevant to the Chinese experience, and specifically linked pollutant reductions with activities, i.e., the transport sector was linked with $\mathrm{NO}_{2}$ reductions, secondary industries with $\mathrm{PM}_{2.5}$ and $\mathrm{CO}$, and $\mathrm{SO}_{2}$ with the industrial sector. Again, greater $\mathrm{O}_{3}$ levels were identified as a result of lower fine particle loadings in the atmosphere [14]. A study on the major economic city cluster known as the Yangtze River Delta region, encompassing Shanghai, identified reduction levels commensurate with mobility restriction and broke down $\mathrm{PM}_{2.5}$ emission sources into industry, responsible for 32.3-61.1\%; mobility (3.9-8.1\%); dust (2.6-7.7\%); residential sources (2.1-28.5\%); and a 14-28.6\% contribution from long-range transport into the region [15]. In addition to the examination of pollutant level reductions as a result of COVID-19, carbon emissions were also reduced by approximately $25 \%$ in China [16].

Investigating other areas of Asia, Malaysia's control order also impacted on $\mathrm{PM}_{2.5}$ pollutant levels. Considering three phases, immediately before the control order (14-17 March) and the first (18-31 March) and second (1-14 April) phases of the order, PM reductions were detected, with the northern region reducing concentrations the most, by $23.7 \%$, exceeded only by areas with high COVID-19 caseloads, which reduced $\mathrm{PM}_{2.5}$ levels by up to $28.3 \%$ [17]. Looking more broadly at South East Asia, a 27-30\% reduction in $\mathrm{NO}_{2}$ levels over the region was identified due to a reduction in anthropogenic and industrial activities, with some variation for seasonal biomass combustion. In addition to $\mathrm{PM}$ results for Malaysia, $\mathrm{NO}_{2}, \mathrm{SO}_{2}$, and $\mathrm{CO}$ concentration decreases were also quantified at $63-64 \%, 9-20 \%$ and $25-31 \%$, respectively. Across South East Asia, notable reductions in aerosol and atmospheric gas levels were identified for industrial, suburban, and rural sites, with the level of reductions commensurate with COVID-19 mobility restrictions [18]. In a study of 22 cities in India between mid-March to mid-April 2020, considering three previous years of data, similar to other nations, reductions in $\mathrm{PM}_{2.5}(43 \%), \mathrm{CO}(10 \%)$, and $\mathrm{NO}_{2}(18 \%)$ were realized, with negligible changes in $\mathrm{SO}_{2}$ and an increase of $17 \%$ in $\mathrm{O}_{3}$ levels, explained by reductions in $\mathrm{PM}$ and $\mathrm{NO}_{2}$ [19].

An investigation of the European cities of Nice, Rome, Turin, and Valencia in comparison with Wuhan was also undertaken, identifying that restrictions on mobility, nonessential business, and industrial activity lead to significant reductions in $\mathrm{NO}_{2}$, linked to the transport sector, and $\mathrm{PM}$, linked to both transport and fuel combustion (though not as high as for Wuhan), as well as a commensurate increase in $\mathrm{O}_{3}$ levels [20]. A recent study of COVID-19 impacts on the Italian carbon footprint identified a $20 \%$ reduction compared to analogous periods from 2015-2019, with the highest savings realized in heavily industrialized areas. These reductions were due to savings in GHG emissions usually associated with energy consumption in the industrial, agricultural, tertiary, and housing sectors of the economy, linked with large reductions in consumption of natural gas, oil, petroleum, and electricity, identifying the potential for GHG savings in the future [21].

The United States of America (USA) has been heavily affected by the COVID-19 pandemic, both in terms of cases and fatalities. A variety of approaches to social distancing and mobility restriction have been implemented across the population. For example, in California, a monitoring of environmental pollutants, including $\mathrm{PM}, \mathrm{CO}, \mathrm{SO}_{2}, \mathrm{NO}_{2}$, and other pollutants, was undertaken between 4 March and 24 April 2020, alongside COVID-19 case numbers and mortalities. A significant correlation was found between the levels of PM, $\mathrm{CO}, \mathrm{SO}_{2}$, and $\mathrm{NO}_{2}$ with COVID-19 cases, and stay at home orders have aided in the reduction of these pollutants in combination with a reduction in economic activity and lower road traffic [22].

In South America, an investigation of the partial lockdown on air quality in Rio de Janeiro in Brazil identified a significant reduction in CO levels of 30.3-48.5\%, with commensurate reductions in $\mathrm{NO}_{2}$ levels and moderate reductions in $\mathrm{PM}_{10}$ levels, which were not sustained as consensus could not be reached on the necessity for social distancing and stay at home orders. The reduction in $\mathrm{NO}_{2}$ meant an increase in $\mathrm{O}_{3}$ levels, as was found in other regions, and indeed experienced previously in Brazil in 2018 as a result of sustained truck driver strike action [23]. 
Studies in other regions including Almaty, Kazakhstan found similar reductions in most pollutants with $49 \%$ and $35 \%$ reduction in $\mathrm{CO}$ and $\mathrm{NO}_{2}$ accompanied by an increase of $15 \%$ in $\mathrm{O}_{3}$ levels. This reduction in pollutants was attributed to an almost complete reduction of transport, however this reduction was accompanied by increased levels of benzene and toluene in the air, attributed to coal fired generation and home-based activities, including garbage incineration. Although PM levels were reduced compared to previous years in the studied period, they were still above World Health Organization (WHO) daily limit values for the majority of assessed days [24]. Also, in north western Morocco, under the restrictions implemented in early March, where cities were locked down and mobility limited including the restriction of unavoidable activities, $\mathrm{PM}_{10}, \mathrm{SO}_{2}$, and $\mathrm{NO}_{2}$ levels where reduced radically, $75 \%, 49 \%$, and $96 \%$, respectively, with $\mathrm{PM}_{10}$ levels satisfying Moroccan daily air quality standards every day of the observed period [25].

In summary, at the global level, reductions in coal-fired power utilization and transportation have meant reductions in GHG emissions for major economies and a reduction by almost half in $\mathrm{NO}_{2}$ emissions in some European cities [26]. Utilizing the mobility index based on Google tracking, significant reductions in transport, grocery and pharmacy, retail, and recreation-based mobility, coupled with moderate residential mobility increases, meant that $\mathrm{NO}_{2}$ levels were reduced by between $20 \%$ and $30 \%$ across China, Europe, and the USA [27]. Substantial reductions in $\mathrm{NO}_{2}$, moderate reductions of aerosol depth, and a mild reduction in CO levels were identified in COVID-19 hotspots between February and March 2020 using global satellite data [28]. Focusing on $\mathrm{CO}_{2}$ emissions, the COVID-19 mobility restrictions were associated with daily global reductions of approximately $17 \%$ compared to 2019 levels, with almost half of these reductions allocated to a reduction in surface transport. Industry emissions were also reduced, with a mild increase in residential emissions due to work-from-home arrangements [29].

It is important to note that for pollutant and aerosol load, meteorology can play an influential role, and many of the studies referenced here mentioned this important caveat.

\subsection{International Cooperation and the Emergence of Nationalism}

The COVID-19 pandemic has highlighted some issues with global supply chains and also brought to light uncooperative national practices with regard to the securing of supplies critical to addressing the pandemic. There is also evidence of silos occurring in terms of broader cooperation, with some contrasting evidence of increased cooperation toward common goals. Finally, nations are re-evaluating existing supply chains and weaknesses engendered by globalization and just-in-time production approaches.

One issue that has been prominent during the COVID-19 crisis is the shortage of personal protective equipment (PPE), essential for protecting healthcare workers. In the USA, shortages of PPE became apparent early on, leading the center for disease control (CDC) to issue guidance for 'optimizing supply' or even replacing face masks with bandanas or scarves in extreme situations [30]. In other nations, shortages lead to internalized bespoke production and the less preferred approach of PPE sterilization to close the shortage gap [31]. Of interest is the management of previously international supply chains, and the move to limit exports of PPE to other nations as a strategy for meeting domestic need [30]. Shortage of PPE was felt most keenly in developed nations, who rely on global supply chains to purchase necessary items from predominantly developing economy nations, leading to the emergence of alternative designs that could be produced using nontraditional materials from alternative supply chains [32]. Nations have also been forced to act flexibly in terms of regulations surrounding the production of PPE, leading in some cases to community-based responses, often employing hobby-level manufacturing approaches, including 3D-printing, as well as the repurposing of manufacturer's production lines [33].

Another issue critical to the conclusion of the COVID-19 pandemic is the development of a vaccine. Many nations are working toward the development of an effective vaccine, some in isolation, and, encouragingly, a large number of trials are operating cooperatively and sharing critical data, 
particularly in the European Union (EU) [34]. The WHO also maintains a database of some 10 vaccines that are in clinical evaluation and a further 126 candidate vaccines in preclinical evaluation [35]. While multiple vaccine approaches, building on global know-how, are being evaluated and moving toward human trials, thanks in part to generous funding arrangements, fears remain that richer, vaccine-producing nations will stockpile doses for their own populations, eschewing a humanitarian distribution approach [36]. Another issue relevant to therapeutic treatments for COVID-19 is the cost-recovery mechanism employed by pharmaceutical companies for medication development, often funded by taxpayers, usually following an initial 'altruistic' contribution of effective treatments. Remdesivir is a prominent example of a current therapeutic treatment that was distributed free of charge in an initial tranche in the USA [37]. Further, although vaccine and therapeutic development efforts move forward cooperatively, scaling up of global supply chains to meet drug development needs may lead to nations imposing restrictions on the export of drugs and chemical precursors in their own self-interest [38], as was the case for PPE in some instances [32].

Cognizant of the need for critical drugs in the treatment of COVID-19 and the strain being imparted on global supply chains, the USA is seeking to address their national vulnerabilities through the reshoring of essential parts of the pharmaceutical supply chain to reduce reliance on foreign-sourced pharmaceuticals [39]. In addition to supply chain concerns surrounding PPE and pharmaceuticals, the United Kingdom (UK) and the USA are seeking to address shortages in qualified medical professionals through aggressive recruiting of foreign candidates, predominantly from low- and middle-income nations, through fast track entry and reduced visa fees. This bolstering of understaffed health systems as a result of nationalism and self-interest has the possibility to undermine medical service growth and staffing levels in affected nations [40].

Considering the diverse approaches to COVID-19 restrictions enacted, and subsequently revised, in each nation, we observed a broad range of responses and effects. In China, the first nation affected by the pandemic, Wuhan city was subject to a travel quarantine on January 23 , followed by a province wide lockdown for the 45 million residents of Hubei on January 30. Along with controlled distribution of food and medicine, emergency field hospitals were erected in response to the outbreak of COVID-19. Across China, these lockdowns were replicated with specific measures controlling moving within provinces or cities and restrictions on entering others. In addition, residents were subject to health status tracking, allowing for the collection of data and tracing of cases [41]. The WHO noted that China's aggressive response, which focused on masks, hygiene, and temperature monitoring, allowed for strong tracing and control of the virus within a relatively short period of time, providing a strong evidence base for other nations [42].

In spite of this practical evidence for dealing with the COVID-19 pandemic, the USA was slow to react, and although the first case was identified on January 20, and all 50 states had declared an emergency by March 27, only 33 states issued stay at home orders, and some nonessential business restrictions. Discretionary travel was allowed in many areas, and social distancing was neither advised nor enforced. This patchwork response was exacerbated by multiple levels of government and a weak lead from the federal government. As a result, the USA became the new epicenter of COVID-19 [43], experiencing the highest number of fatalities globally.

In Europe, Italy was the first nation to impose restrictions from March 9 to limit social interaction and virus spread. These restrictions were not reduced until May 4 to allow factories and parks to reopen, and then June 3 to allow international travel in and out of the nation. Italy was also the hardest hit nation in Europe, with a fatality rate of approximately $4 \%$. As Italy's disaster was estimated to precede those of other European nations by 2-3 weeks, it was highlighted as a lesson for other nations in Europe to enact restrictive policies [44]. This lesson from Italy was not capitalized on in the UK, and in fact, no response or restriction on movement or public gathering was enforced in the first weeks of March. Also, the idea of herd immunity was floated by the chief science advisor (although not as national policy), and some self-isolation was finally advised for those with a fever or persistent cough, or those living with such people on March 16. The economy was prioritized, and it was not 
until scientific evidence regarding the likely overwhelming of the National Health Service (NHS) was presented, that restrictions such as school closures were implemented. Exacerbated by limited PPE and a depleted NHS [45], the UK experience has been worse than that of Italy.

Sweden is an outlier in the overall European approach, which sought 'herd immunity', i.e., no intervention policy, and hospital resources prioritized toward those most likely to survive, recognizing that under the herd immunity approach, these resources would not be sufficient for all affected members of society [46]. Sweden was criticized for this approach, under the assumption that a greater number of deaths would occur as a result, while it has also been suggested that this approach combines scientific data and back casting, and is cognizant of future developments, including the wide availability of a vaccine [46]. In terms of making sense of the different outcomes experienced in each nation, the five factors of demographic characteristics, definition of COVID-19-related deaths, differences in testing strategies, health care system variations, and preventive strategies have been identified as critical to determining case fatality rates [47].

Although there is a growing body of scientific evidence, national governments are choosing to ignore other nations experiences and the reporting of the $\mathrm{WHO}$ and other health agencies, choosing to go it alone, often in a patchwork manner. This is in spite of the fact that proven measures such as social distancing and masks have benefits not only to the local population but also to national and global communities in terms of reducing overall infections and the strain on healthcare [48].

\subsection{Achievement of Carbon Targets and the Energy Transition}

While COVID-19 restrictions have reduced carbon emissions, alongside other GHGs, pollutants, and aerosols, the easing of these restrictions is likely to see an uptick in emission levels. This has already been noted in parts of China, the earliest affected region of the pandemic [11,12]. One suggested approach emerging from the pandemic is the concept of 'glocalization'. Through the localization of production and the reduction of air and surface travel, glocalization aims to alleviate the impacts of the pandemic while addressing the economic and environmental crises at hand [10]. At the very least, by understanding the short-term impacts of COVID-19 on carbon emissions, certain nations may find it easier to meet their 2030 carbon targets, and, while sustaining post-COVID-19 carbon levels may not be possible, some decoupling of the economy and emissions may be achievable. In terms of the economic flow-on effects of the pandemic, fiscal easing in particular (i.e., government financial support and reduction of interest rates) may reduce investment costs for renewable and other low-carbon technologies, so long as governments and investors choose to prioritize these investments [26].

As a result of the supply chain disruptions, which affected both PPE and pharmaceuticals, renewable and sustainable energy supply chains have also been disrupted. This will inevitably lead to a short-run negative impact on these industries, and it has been suggested that energy and climate policies will need to be restructured to account for these impacts, and that governments will need to encourage additional investment in renewables in order to meet long-term environmental goals [49]. The ability to capitalize on carbon emission and pollution downturns experienced during the COVID-19 pandemic will depend on a nation's ability to restructure the energy system-this ability will also hinge on the overall economic impacts of COVID-19. Three principled recommendations are suggested, including the avoidance of overreaction to exogenous impacts in the short-term, leveraging new opportunities to progress the energy transition in the mid-term, and to develop future policy that is resilient to exogenous shocks [50]. Recognizing that climate change and COVID-19 are both global issues which require a coordinated policy response, Rosenbloom and Markand saw a strategic opportunity in the economic recovery from COVID-19 to transition to a more sustainable world [51].

Although all nations are directing resources toward the amelioration of the economic and social impacts of COVID-19, they are doing so in different ways. Germany and the USA have been highlighted as focusing on incumbent industries, overlooking climate change, and in some cases repealing environmental regulations to stimulate economic activity. On the other hand, there has been support for the European Commission to prioritize the 'Green Deal' in their post-pandemic recovery. 
Indeed, the pandemic has been highlighted as an opportunity to progress the transition to a more sustainable energy system, harnessing the disruption caused by COVID-19 [51]. When considering that some of the key technologies that are progressing the energy transition are wind and solar, the reduced demand for installations due to the virus (estimated at approximately $10 \mathrm{GW}$ globally [52]) is of concern, and the International Energy Agency (IEA) has suggested that the essential task of building a sustainable energy future should not lose impetus because of COVID-19 [53].

Prioritizing funding to energy efficiency and renewable energy sectors post-pandemic is essential for a successful transition, as these industries show significant job growth in the US [54]. Governments are also in a unique position as incumbent energy suppliers, often fossil fuel based, are requesting financial assistance in tough economic circumstances. This situation gives governments (without vested interests in fossil fuel incumbency) a rare opportunity to attach financial aid to regulations and efficiency requirements. This opportunity, coupled with low-cost, low-carbon energy alternatives, may engender a restructuring of the energy system toward a sustainable future [55]. Another positive aspect of renewable energy identified in the EU as a result of COVID-19-induced energy demand reductions was the increase in the energy generation share from renewable by $8 \%$ compared to 2019 levels, up to a total of $43 \%$. The European response to COVID-19 has been enthusiastically estimated by the Wartsila Energy Transition Lab to have accelerated the EU energy transition by a decade [56].

Table 1 summarizes the potential post-COVID-19 approaches (both positive and negative) that have been identified in different regions and their likely future impacts.

Table 1. Summary of post-COVID-19 approaches and potential impacts.

\begin{tabular}{|c|c|}
\hline Post-COVID-19 Proposed Approaches & Potential Future Impacts \\
\hline $\begin{array}{l}\text { Glocalization: the localization of production and } \\
\text { reduction of travel. }\end{array}$ & $\begin{array}{l}>\text { Reduce the impacts of the pandemic } \\
>\text { Address economic and environmental crises }\end{array}$ \\
\hline $\begin{array}{l}\text { Government financial support: reduce interest rates, } \\
\text { prioritization, and additional investment in } \\
\text { renewables }\end{array}$ & $\begin{array}{l}>\text { Reduce investment costs for renewable and } \\
\text { low-carbon technologies } \\
>\text { Meet long-term environmental goals }\end{array}$ \\
\hline $\begin{array}{l}\text { Capitalize on carbon emission and pollutant } \\
\text { downturns }\end{array}$ & $>$ Identify the need to restructure the energy system \\
\hline Principled approach to recovery & $\begin{array}{l}>\text { Avoid overreaction to exogenous impacts } \\
>\text { Leverage opportunities to progress the energy } \\
\text { transition } \\
>\text { Develop future policy which is resilient }\end{array}$ \\
\hline Focusing on incumbent industries & $\begin{array}{l}>\text { Stimulate the economy by repealing } \\
\text { environmental regulations } \\
>\text { Exacerbate climate change }\end{array}$ \\
\hline $\begin{array}{l}\text { Prioritizing the 'Green Deal' suite of policies: } \\
\text { harnessing the disruption caused by COVID-19 }\end{array}$ & $\begin{array}{l}>\text { Progress the energy transition to a more } \\
\text { sustainable energy system }\end{array}$ \\
\hline $\begin{array}{l}\text { Prioritizing funding to energy efficiency and } \\
\text { renewable energy sectors }\end{array}$ & $\begin{array}{l}>\text { Sustain strong job growth } \\
>\text { Engender a successful transition }\end{array}$ \\
\hline $\begin{array}{l}\text { Link financial aid to fossil fuel energy providers with } \\
\text { regulations and efficiency requirements, coupled with } \\
\text { low-cost, low-carbon alternatives }\end{array}$ & $\begin{array}{l}\text { Encourage a restructuring of the energy system } \\
\text { toward a sustainable future system }\end{array}$ \\
\hline
\end{tabular}

Building on analysis that identified an average drop of $\mathrm{CO}_{2}$ emissions by $17 \%$ (considering $97 \%$ of global emissions [29]) due to restrictions put in place to respond to the pandemic, it is estimated that annual emissions may fall from between $4 \%$ and $7 \%$ depending on the end date and easing rate of restrictions. Behaviors employed during the COVID-19 restrictions may provide hints for future energy policy development, such as incentivizing work-from-home approaches and remote attendance to meetings and conferences. However, considering the limited reduction in $\mathrm{CO}_{2}$ emissions foreseen from such activities in isolation, we can also realize the limit of individual behaviors on overall emissions [57]. 
At the very least, the COVID-19 pandemic will bring greater attention to the challenge of mitigating climate change, with the United Nations Environment Program (UNEP) estimating that GHGs must be reduced 7.6\% each and every year between 2020 and 2030 in order to meet Paris Agreement 1.5 degree Goals [58], in excess of the reductions estimated to be due to COVID-19 induced slow-downs.

Figure 1 details the nations and regions investigated in this study in terms of reduced mobility, aerosols and GHG emissions, cooperation and nationalism, and achievement of carbon targets and the energy transition. These nations were selected for the significance of COVID-19 impacts and data availability in the reviewed literature from scientific journal databases and supporting secondary data.

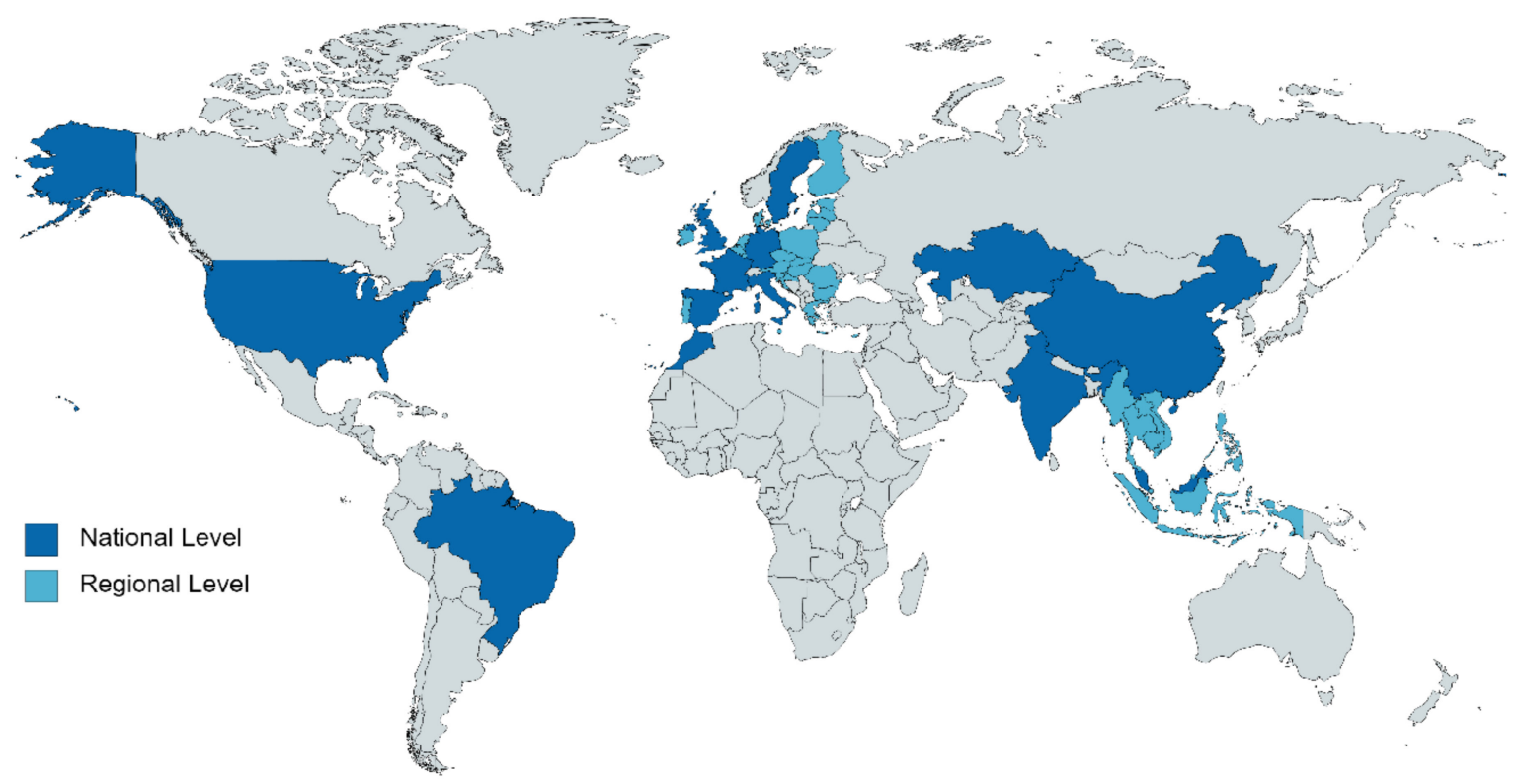

Figure 1. Nations and regions investigated in this study.

\section{Discussion}

Considering the impacts of the COVID-19 pandemic on mobility and emissions, international cooperation, and the energy transition, policy implications were extracted relevant to achieving global carbon reduction goals. Building on this analysis, necessary policy actions have been developed, which will engender a successful energy transition and global cooperation to meet the challenges of a low carbon future and achievement of the SDGs identified as most impacted by the COVID-19 crisis.

\subsection{Policy Implications}

Taking into account the finding that reduced mobility and a shift to work-from-home arrangements has reduced aerosol pollutants and GHG emissions, bringing some nations closer to achieving their annual carbon reduction goals, COVID-19 provides governments and individuals with evidence to adapt learnings from the lockdown toward longer term solutions [27]. These solutions may be as simple as providing incentives for individuals who are able to continue to work from home, or as complex as restructuring transport regimes and manufacturing processes. The COVID-19 pandemic has forced governments to act in the interest of their citizens, however, this has not been the case for global warming, or the known impacts of poor air quality, although the rationalization of the potential impacts (in terms of morbidity and fatalities) of unchecked climate change may be a catalyst for future interventions [46]. COVID-19 stands as a lesson to governments that we need to support and strengthen health systems to ensure our own and other nation's safety and health in times of emergency [40], and perhaps this analogy will hold true for the global emergency of climate change and the need for a successful energy transition. This point is reinforced by the fact that reductions in $\mathrm{NO}_{2}, \mathrm{SO}_{2}, \mathrm{PM}_{2.5}$, and $\mathrm{CO}_{2}$, while positive, had the side effect of increased $\mathrm{O}_{3}$ levels in the atmosphere, 
exacerbating some cardiorespiratory health risks and comorbidities [59]—policy needs to be aware of the breadth of scientific evidence.

The identification of the limit of individual actions upon carbon emissions due to restrictions during the pandemic also provides strong evidence moving forward of the scale of action required for nations to meet their Paris Agreement obligations [57]. Even under the assumption that a portion of the carbon emission savings realized during lockdown can be maintained, and that nationally determined contributions (NDC) under the Paris Agreement are fulfilled, the ambitious 1.5 degree Celsius temperature increase target is unlikely to be met [60]. The International Panel on Climate Change (IPCC) report on limiting temperature changes as a result of climate change requires specific actions including a price on carbon, targeted investment in mitigation, carbon negative technologies (e.g., direct air capture (DAC) or biomass energy with CCS (BECCS)) and identified the lack of global cooperation as a major roadblock to achieving climate change mitigation goals [60]. Parallels to the COVID-19 pandemic situation are echoed by the IPCC report.

As an alternative to engaging carbon-negative technologies as a mitigation strategy for likely GHG emission overruns, there is conjecture that a change in lifestyle, including a shift to eating less meat, consuming less, using less transport, and modifying heating and cooling behaviors, along with reforestation efforts, could also meet ambitious Paris Agreement goals [61]. Prior to COVID-19, this wholesale reconsideration of mobility and behavior may have been outside of the realms of plausible policy options, however following our shared experience under COVID-19 restrictions, this reshaping of societal norms may no longer be so farfetched. The reorganization of society in recognition of unsustainable economic practices and discrimination against specific societal groups toward a more equal and sustainable approach has been investigated, suggesting that a return to normal is not the correct answer in this case [62].

Weaknesses identified in the global supply chain, particularly for PPE and pharmaceuticals, have highlighted the issues surrounding supply chain resilience, relevant also to renewable energy [50]. Perhaps as a result of nationalist tendencies, several nations have suggested moving toward a local production-local consumption model, which may increase the cost of the energy transition. This nationalist approach to emerging issues also has relevance to the energy transition and achievement of global environmental goals, with the clustering of resources and know-how likely counterproductive to the achievement of climate change mitigation targets.

Additionally, evidence from the COVID-19 slowdown in terms of both the economy, emissions, and the energy transition suggests that the post-COVID-19 economic restart should prioritize job-creating industries, among which renewable energy is prominent [54].

Summarizing the necessity for action toward meeting Paris Agreement carbon reduction goals and capitalizing on COVID-19 learnings, Figure 2 outlines four pathways. In order to achieve the ambitious 1.5 degree target by 2030 , a reduction of more than $50 \%$ of carbon intensity is required.

Current policies increase carbon emission intensity, while the NDS scenario pathway can engender approximately $2 \%$ reductions [58]. In 2020, COVID mobility restrictions engendered a $17 \%$ GHG cut, however following the anticipated uptick, and following implementation of higher levels of glocalization and work from home arrangements, this is expected to reduce to around $7 \%$, using an optimistic estimate [57].

Without capitalizing on COVID-19 learnings, the necessary contributions from further lifestyle changes, carbon reducing, and carbon-negative technologies would be significantly increased, demonstrated by the green arrow (2) in Figure 2. Capitalizing on COVID-19 learnings would reduce the pressure on individuals to alter their lifestyles, and on policy intervention severity in terms of technological responses, represented by the blue arrow (1) in Figure 2. 


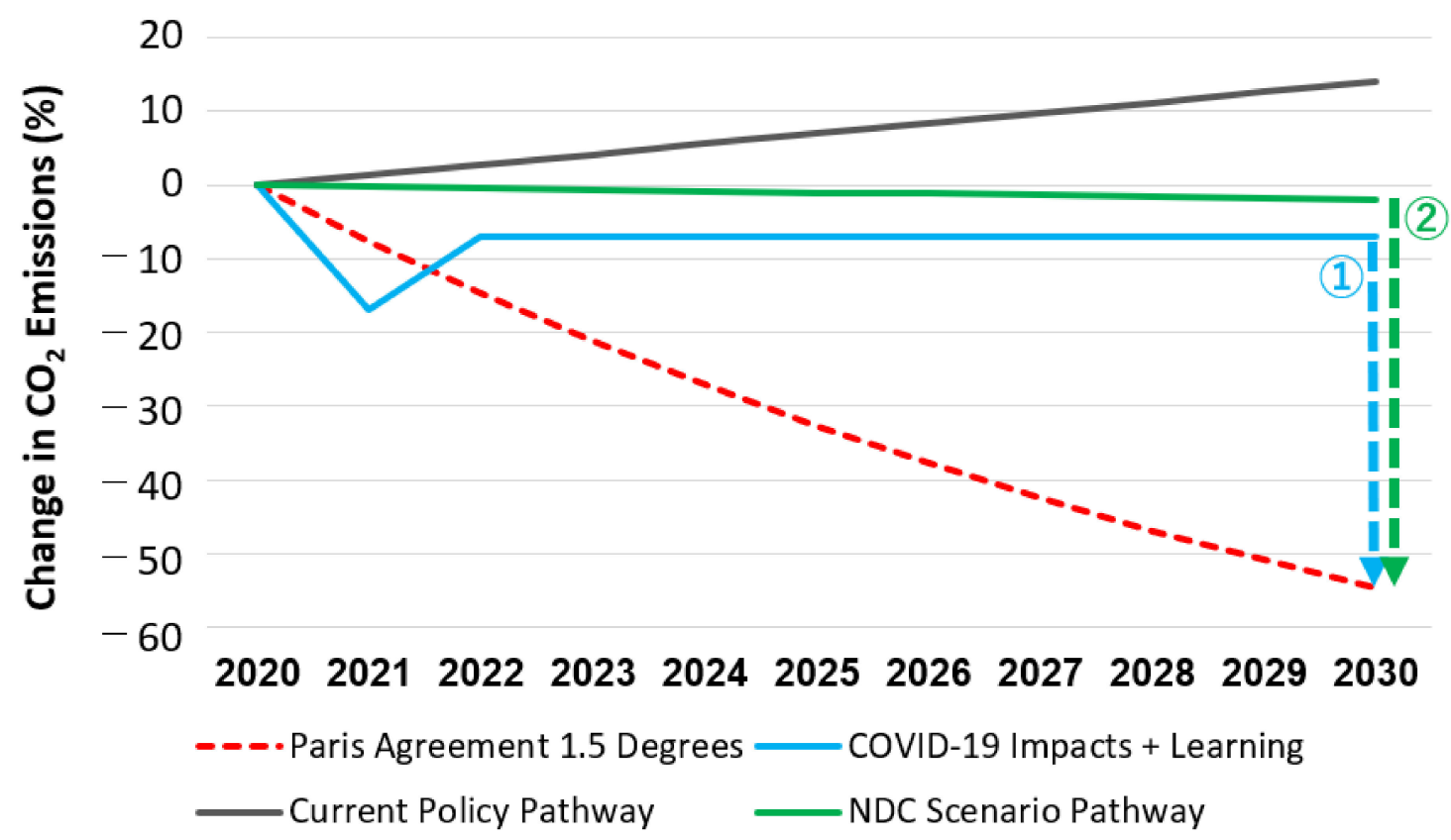

Figure 2. Carbon emission pathways and targets.

\subsection{Necessary Policy Actions and Impacted SDGs}

Building on the relevant evidence uncovered by COVID-19 scholarship, a number of opportunities for policy that capitalizes on learnings and science-based findings have been identified, allowing for a 'change of direction' [62].

The impacts of the COVID-19 pandemic have been global in nature and have interrupted many aspects of our daily lives. Responding to these impacts will require a consideration of the body of global knowledge, best practice, and a shift away from nationalist approaches in favor of international learning and a strengthening of global cooperative systems.

Further, considering the bevy of approaches implemented in dealing with the COVID-19 crisis, the absence of guiding, science-based leadership was evident. It is likely that time was lost seeking appropriate actions by following those which sought to appease stakeholders or limit restrictions on people's daily lives-these lessons need to be recognized and applied to the global climate change crisis, and the impact of politics on decision-making needs to be reduced.

In adopting science-based approaches that work in the interest of achieving goals (rather than appeasing stakeholders), we have an opportunity to retool global cooperative organizations such that critical global goals are prioritized and best practices are shared, rather than a piecemeal approach in which national interests trump those of our shared global environment.

Resilience issues identified in supply chains as a result of the COVID-19 pandemic also bear policy lessons for the energy transition. Local production and consumption is one solution to strengthening supply chains, i.e., the reshoring of industries previously located internationally, however, market impacts suggest that sharing costs through cooperative approaches may yield better results than reshaping supply chains to meet the needs of individual nations. Pushing growth industries in terms of meeting energy transition and climate change goals while generating new jobs has also emerged as a critical post-COVID-19 strategy, engendering the co-benefit of boosting the economic restart.

Finally, recognizing the limitations of individual actions and the environmental improvements (temporarily) offered by COVID-19, a focus on the development of necessary technologies (including carbon-neutral and carbon-negative approaches), as well as the consideration of lifestyle-based policies to achieve required carbon reductions, remain necessary. Engaging the above policy recommendations 
based on the academic evidence arising from the COVID-19 pandemic represents an opportunity for nations to prioritize environmental sustainability and leverage learnings to a positive outcome.

Cognizant of policy implications, SDGs that are most impacted both by COVID-19 and the energy transition can be identified, further aiding policymakers in their pinpointing of necessary policy actions. Key issues of the COVID-19 pandemic and related energy policy issues were extracted from the literature review sections and summarized in Table 2, linked to related SDGs [63].

Table 2. Identified issues, factors and impacted Sustainable Development Goals (SDGs) (authors own work, SDG icons from UN SDG communication materials).

\begin{tabular}{|c|c|c|}
\hline Identified Issues & Specific Factors & Impacted SDGs \\
\hline Air quality changes & $\begin{array}{c}\mathrm{NO}_{2}, \mathrm{SO}_{2}, \mathrm{PM} \text { decrease, } \mathrm{O}_{3} \\
\text { increase }\end{array}$ & 36 \\
\hline Reduced GHG emissions & $\begin{array}{l}\text { Reductions in } \mathrm{CO}_{2} \text { due to reduced } \\
\text { mobility and work from home }\end{array}$ & \\
\hline Changes in consumption behavior & $\begin{array}{l}\text { Work from home, avoiding } \\
\text { shopping in person }\end{array}$ & \\
\hline Supply chain disruption & $\begin{array}{l}\text { Short-term negative impacts on } \\
\text { renewable energy industries, shifts } \\
\text { to alternative production methods }\end{array}$ & 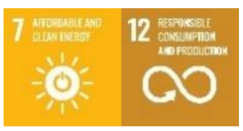 \\
\hline $\begin{array}{l}\text { Unemployment due to economic } \\
\text { downturn }\end{array}$ & $\begin{array}{l}\text { Loss of jobs that do not adapt to } \\
\text { work from home, focus on job } \\
\text { growth in economic restart }\end{array}$ & \\
\hline $\begin{array}{c}\text { International cooperation and } \\
\text { nationalism }\end{array}$ & $\begin{array}{l}\text { Material shortages, hoarding, } \\
\text { various mitigation approaches, } \\
\text { research and development } \\
\text { cooperation or silos }\end{array}$ & $\begin{array}{c}17 \\
16\end{array}$ \\
\hline $\begin{array}{l}\text { Shifting to alternative economic } \\
\text { and industrial approaches } \\
\text { post-COVID-19 }\end{array}$ & $\begin{array}{l}\text { Glocalization, fiscal easing, } \\
\text { revising of supply chains }\end{array}$ & 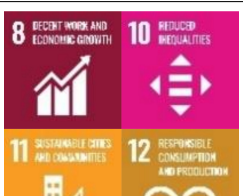 \\
\hline $\begin{array}{l}\text { COVID-19-induced social } \\
\text { transitions }\end{array}$ & $\begin{array}{l}\text { Favoring incumbent industries or } \\
\text { encouraging restructuring to } \\
\text { engender energy transitions }\end{array}$ & 7 mesters \\
\hline Technological and social structures & $\begin{array}{l}\text { Meeting climate change through } \\
\text { more aggressive technological } \\
\text { intervention and/or through } \\
\text { lifestyle changes }\end{array}$ & 12 \\
\hline
\end{tabular}

UN Sustainable Development Goals Communication Materials available from: https://www.un.org/ sustainabledevelopment/news/communications-material/. 
Although Table 2 provides a summary of the top-level SDGs relevant to the energy transition through the lens of the COVID-19 pandemic, due to the broad nature of some SDGs, a significant number of the 17 are often identified as relevant or important when investigating energy or environmental issues [64]. This is also true in this analysis, where a total of 11 of 17 SDGs were identified as impacted, and those which were not identified as impactful (1: no poverty, 2: zero hunger, 4: quality education, 5: gender equality, 6: clean water and sanitation, and 14: life below water) are likely peripheral issues relevant to the energy transition or other SDGs. In order to overcome this issue, and identify the most critical SDGs in this case, the above analysis was contrasted with SDG achievement trajectories according to national SDG dashboards [65] for the significantly impacted nations of China, USA, UK, Italy, Spain, and Brazil from the literature.

Taking the simple approach of identifying those SDGs that are on track to be achieved, have scores increasing yet insufficient to attain the goal, or whose scores are not progressing well [65], we can provide advice for policymakers on where to best focus their efforts in order to achieve a sustainable energy transition in each nation, as shown in Table 3.

Table 3. Impacted SDG scorecard (SDGs with insufficient information are excluded; authors own work, adapted from [65]).

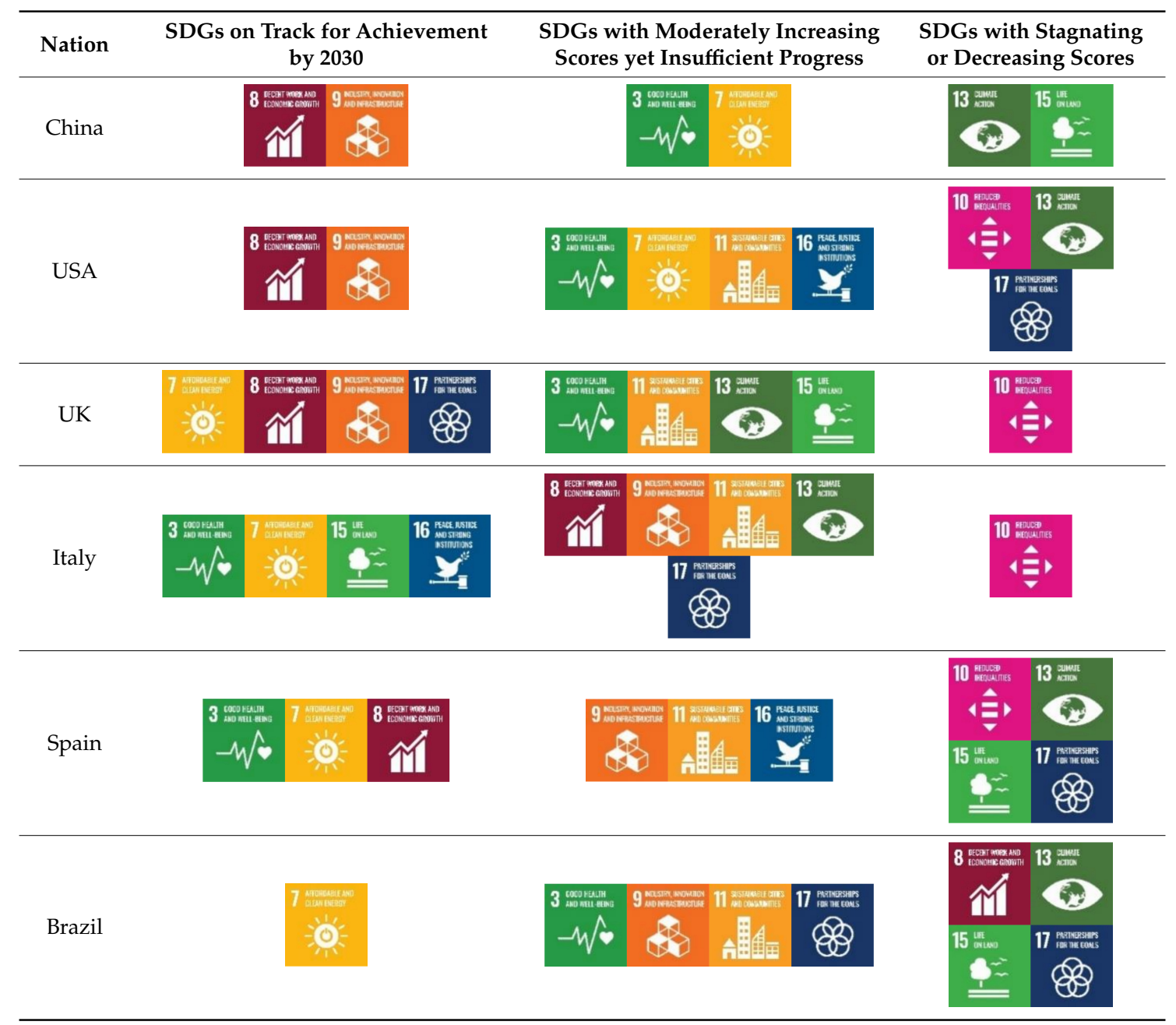

Although Table 3 does not provide a complete picture, with some countries unable to provide information for all SDGs, the common occurrence of reduced inequalities, climate action, and partnerships for the goals, SDGs 10,13, and 17 as scores that are stagnating or decreasing in four of the six analyzed nations suggests that these are not only priority SDGs, but common priority SDGs, 
which will likely be solved cooperatively rather than in isolation. These SDGs have been highlighted by the COVID-19 crisis and may help policymakers to refocus efforts in critical areas to engender a fair, cooperative global energy transition. On a positive note, the assessed nations appear to be making good strides toward achieving SDG 7 (affordable and clean energy) and SDG 8 (decent work and economic growth), while mixed results have been seen for a large number of SDGs in the 'insufficient progress' column in Table 3, including SDG 3 (good health and wellbeing) and SDG 11 (sustainable cities and communities).

\section{Conclusions}

By undertaking a review of the impacts of COVID-19 on mobility, pollutants, and carbon emissions, cognizant of the emergence of and challenges presented by nationalist and cooperative approaches, it has been possible to derive policy implications for the achievement of the energy transition and cooperative carbon reduction goals. In addition, capturing the impacts of COVID-19 and the need for policy action, an evaluation of impacted and common critical SDGs was conducted, identifying SDG 10 (reduced inequalities), 13 (climate action), and 17 (partnerships for the goals) as crucial to future success.

Scientists and policy makers alike rely on empirical evidence to develop theories and test scenarios. The COVID-19 pandemic, while devastating in terms of the human cost and interruption to society and the economy, has provided a solid evidence base on which to develop future policy that can capitalize on the learnings surrounding telework initiatives, diversifying of supply chains, sharing of know-how, and working together in areas of common interest. On the other hand, in spite of the glut of scientific evidence supporting cooperative approaches and learning form international experience, national governments have not necessarily chosen to leverage this evidence base for their policymaking and have chosen to go it alone, in a haphazard manner.

The COVID-19 pandemic has forced us to recognize that the earth is a closed system, evidenced by the rapid, wide spread of the virus across the globe. This crisis is a pertinent analogue of the challenge of climate change, also occurring in the shared space of our globe. If policymakers and governments can capitalize on the idea of a shared, closed earth system, as has been promulgated by the COVID-19 pandemic, there is hope that a combined, shared approach to climate change will also be possible in the future.

There are some limitations to this study, as the COVID-19 pandemic is a situation in flux, the documents referred to are very recent and ongoing effects of the pandemic may influence future reporting. As the pandemic has worsened over time, we feel that the impacts will worsen in the short term rather than improve, and that the results of this review will remain relevant in this case.

Author Contributions: Both authors (A.C. and T.T.) contributed equally to all parts of this article. All authors have read and agreed to the published version of the manuscript.

Funding: This research received no external funding.

Conflicts of Interest: The authors declare no conflict of interest.

\section{References}

1. Liu, Y.C.; Kuo, R.L.; Shih, S.R. COVID-19: The First Documented Coronavirus Pandemic in History. Biomed. J. 2020, in press. [CrossRef] [PubMed]

2. United Nations Framework Convention on Climate Change (UNFCC). Paris Agreement on Climate Change; United Nations: Paris, France, 2015.

3. United Nations. The sustainable development goals report 2019. United Nations Publ. Issued Dep. Econ. Soc. Aff. 2019, 64.

4. Ho, K.-F.; Lin, L.-Y.; Weng, S.-P.; Chuang, K.-J. Medical mask versus cotton mask for preventing respiratory droplet transmission in micro environments. Sci. Total Environ. 2020, 735, 139510. [CrossRef] [PubMed] 
5. Cowling, B.J.; Ali, S.T.; Ng, T.W.Y.; Tsang, T.K.; Li, J.C.M.; Fong, M.W.; Liu, Q.; Kwan, M.Y.W.; Lee, L.S.; Chiu, S.S.; et al. Impact assessment of non-pharmaceutical interventions against coronavirus disease 2019 and influenza in Hong Kong: An observational study. Lancet Public Health 2020, 5, e279-e288. [CrossRef]

6. Iacus, S.M.; Natale, F.; Santamaria, C.; Spyratos, S.; Vespe, M. Estimating and projecting air passenger traffic during the COVID-19 coronavirus outbreak and its socio-economic impact. Saf. Sci. 2020, 129, 104791. [CrossRef] [PubMed]

7. Abd El-Aziz, T.M.; Stockand, J.D. Recent progress and challenges in drug development against COVID-19 coronavirus (SARS-CoV-2)-an update on the status. Infect. Genet. Evol. 2020, 83, 104327. [CrossRef] [PubMed]

8. NBC News. Coronavirus Vaccine: White House Narrows Focus, a Billionaire Scientist Jumps in the Race. 2020. Available online: https://www.nbcnews.com/science/science-news/coronavirus-vaccine-white-housenarrows-focus-billionaire-scientist-jumps-race-n1225886 (accessed on 10 June 2020).

9. Mesa Vieira, C.; Franco, O.H.; Gómez Restrepo, C.; Abel, T. COVID-19: The forgotten priorities of the pandemic. Maturitas 2020, 136, 38-41. [CrossRef]

10. Goffman, E. In the wake of COVID-19, is glocalization our sustainability future? Sustain. Sci. Pract. Policy 2020, 16, 48-52. [CrossRef]

11. Fan, C.; Li, Y.; Guang, J.; Li, Z.; Elnashar, A.; Allam, M.; de Leeuw, G. The Impact of the Control Measures during the COVID-19 Outbreak on Air Pollution in China. Remote Sens. 2020, 12, 1613. [CrossRef]

12. Zhang, R.; Zhang, Y.; Lin, H.; Feng, X.; Fu, T.-M.; Wang, Y. NOx Emission Reduction and Recovery during COVID-19 in East China. Atmosphere (Basel) 2020, 11, 433. [CrossRef]

13. Bao, R.; Zhang, A. Does lockdown reduce air pollution? Evidence from 44 cities in northern China. Sci. Total Environ. 2020, 731, 139052. [CrossRef] [PubMed]

14. Wang, Y.; Yuan, Y.; Wang, Q.; Liu, C.; Zhi, Q.; Cao, J. Changes in air quality related to the control of coronavirus in China: Implications for traffic and industrial emissions. Sci. Total Environ. 2020, 731, 139133. [CrossRef] [PubMed]

15. Li, L.; Li, Q.; Huang, L.; Wang, Q.; Zhu, A.; Xu, J.; Liu, Z.; Li, H.; Shi, L.; Li, R.; et al. Air quality changes during the COVID-19 lockdown over the Yangtze River Delta Region: An insight into the impact of human activity pattern changes on air pollution variation. Sci. Total Environ. 2020, 732. [CrossRef] [PubMed]

16. Isaifan, R.J. The dramatic impact of Coronavirus outbreak on air quality: Has it saved as much as it has killed so far? Glob. J. Environ. Sci. Manag. 2019, 6, 275-288. [CrossRef]

17. Abdullah, S.; Mansor, A.A.; Napi, N.N.L.M.; Mansor, W.N.W.; Ahmed, A.N.; Ismail, M.; Ramly, Z.T.A. Air quality status during 2020 Malaysia Movement Control Order (MCO) due to 2019 novel coronavirus (2019-nCoV) pandemic. Sci. Total Environ. 2020, 729, 139022. [CrossRef]

18. Kanniah, K.D.; Kamarul Zaman, N.A.F.; Kaskaoutis, D.G.; Latif, M.T. COVID-19's impact on the atmospheric environment in the Southeast Asia region. Sci. Total Environ. 2020, 736, 139658. [CrossRef]

19. Sharma, S.; Zhang, M.; Anshika Gao, J.; Zhang, H.; Kota, S.H. Effect of restricted emissions during COVID-19 on air quality in India. Sci. Total Environ. 2020, 728, 138878. [CrossRef]

20. Sicard, P.; De Marco, A.; Agathokleous, E.; Feng, Z.; Xu, X.; Paoletti, E.; Calatayud, V. Amplified ozone pollution in cities during the COVID-19 lockdown. Sci. Total Environ. 2020, 735, 139542. [CrossRef]

21. Rugani, B.; Caro, D. Impact of COVID-19 outbreak measures of lockdown on the Italian Carbon Footprint. Sci. Total Environ. 2020, 737, 139806. [CrossRef]

22. Bashir, M.F.; Bilal, B.M.; Komal, B. Correlation between environmental pollution indicators and COVID-19 pandemic: A brief study in Californian context. Environ. Res. 2020, 187, 109652. [CrossRef]

23. Dantas, G.; Siciliano, B.; França, B.B.; da Silva, C.M.; Arbilla, G. The impact of COVID-19 partial lockdown on the air quality of the city of Rio de Janeiro, Brazil. Sci. Total Environ. 2020, 729. [CrossRef] [PubMed]

24. Kerimray, A.; Baimatova, N.; Ibragimova, O.P.; Bukenov, B.; Kenessov, B.; Plotitsyn, P.; Karaca, F. Assessing air quality changes in large cities during COVID-19 lockdowns: The impacts of traffic-free urban conditions in Almaty, Kazakhstan. Sci. Total Environ. 2020, 730, 139179. [CrossRef] [PubMed]

25. Otmani, A.; Benchrif, A.; Tahri, M.; Bounakhla, M.; Chakir, E.M.; El Bouch, M.; Krombi, M. Impact of Covid-19 lockdown on PM10, SO2 and NO2 concentrations in Salé City (Morocco). Sci. Total Environ. 2020, 735, 139541. [CrossRef] [PubMed]

26. Helm, D. The Environmental Impacts of the Coronavirus. Environ. Res. Econ. 2020, 76, 21-38. [CrossRef] [PubMed] 
27. Muhammad, S.; Long, X.; Salman, M. COVID-19 pandemic and environmental pollution: A blessing in disguise? Sci. Total Environ. 2020, 728, 138820. [CrossRef]

28. Lal, P.; Kumar, A.; Kumar, S.; Saikia, P.; Dayanandan, A.; Adhikari, D.; Khan, M.L. The dark cloud with a silver lining: Assessing the impact of the SARS COVID-19 pandemic on the global environment. Sci. Total Environ. 2020, 732, 139297. [CrossRef]

29. Le Quéré, C.; Jackson, R.B.; Jones, M.W.; Smith, A.J.P.; Abernethy, S.; Andrew, R.M.; De-Gol, A.J.; Willis, D.R.; Shan, Y.; Canadell, J.G.; et al. Temporary reduction in daily global CO2 emissions during the COVID-19 forced confinement. Nat. Clim. Chang. 2020, 248, 1-7. [CrossRef]

30. Todd, B. Where Are the Masks? Am. J. Nurs. 2020, 120, 18-19. [CrossRef]

31. Rowan, N.J.; Laffey, J.G. Challenges and solutions for addressing critical shortage of supply chain for personal and protective equipment (PPE) arising from Coronavirus disease (COVID19) pandemic-Case study from the Republic of Ireland. Sci. Total Environ. 2020, 725, 138532. [CrossRef]

32. Shokrani, A.; Loukaides, E.G.; Elias, E.; Lunt, A.J.G. Exploration of alternative supply chains and distributed manufacturing in response to COVID-19; a case study of medical face shields. Mater. Des. 2020, 192, 108749. [CrossRef]

33. Flanagan, S.T.; Ballard, D.H. 3D Printed Face Shields: A Community Response to the COVID-19 Global Pandemic. Acad. Radiol. 2020, 27, 905-906. [CrossRef] [PubMed]

34. Blomberg, N.; Lauer, K.B. Connecting data, tools and people across Europe: ELIXIR's response to the COVID-19 pandemic. Eur. J. Hum. Genet. 2020, 28, 719-723. [CrossRef] [PubMed]

35. World Health Organization. Draft Landscape of COVID-19 Candidate Vaccines-15 May 2020. Who 2020. Available online: https:/www.who.int/who-documents-detail/draft-landscape-of-covid-19-candidatevaccines (accessed on 12 June 2020).

36. Mukherjee, R. Global efforts on vaccines for COVID-19: Since, sooner or later, we all will catch the coronavirus. J. Biosci. 2020, 45. [CrossRef]

37. CNN. The US Government's Supply of Covid-19 Drug Remdesivir Runs Out at the End of the Month 2020. Available online: https://www.cnn.com/2020/06/07/health/remdesivir-donation-runs-out-coronavirus/index. html (accessed on 12 June 2020).

38. Yu, D.E.C.; Razon, L.F.; Tan, R.R. Can global pharmaceutical supply chains scale up sustainably for the COVID-19 crisis? Res. Conserv. Recycl. 2020, 159, 104868. [CrossRef] [PubMed]

39. Gurvich, V.J.; Hussain, A.S. In and Beyond COVID-19: US Academic Pharmaceutical Science and Engineering Community Must Engage to Meet Critical National Needs. AAPS PharmSciTech 2020, 21, 153. [CrossRef]

40. Fagan, J.J.; Cairncross, L.; Biccard, B.; Fieggen, G.; Maswime, S. COVID-19 exposes health worker shortages in the USA and UK, but nationalism and self-interest must not exploit medical workforces from low- and middle-income countries. S. Afr. Med. J. 2020, 110, 335. [CrossRef]

41. Liu, W.; Yue, X.G.; Tchounwou, P.B. Response to the covid-19 epidemic: The chinese experience and implications for other countries. Int. J. Environ. Res. Public Health 2020, 17, 2304. [CrossRef]

42. World Health Organization (WHO). Report of the WHO-China Joint Mission on Coronavirus Disease 2019 (COVID-19). 2020. Available online: https://www.who.int/docs/default-source/coronaviruse/who-chinajoint-mission-on-covid-19-final-report.pdf (accessed on 12 June 2020).

43. Haffajee, R.L.; Mello, M.M. Thinking Globally, Acting Locally-The U.S. Response to Covid-19. N. Engl. J. Med. 2020, 382, e75. [CrossRef]

44. Saglietto, A.; D'Ascenzo, F.; Zoccai, G.B.; De Ferrari, G.M. COVID-19 in Europe: The Italian lesson. Lancet 2020, 395, 1110-1111. [CrossRef]

45. Hunter, D.J. Covid-19 and the Stiff Upper Lip-The Pandemic Response in the United Kingdom. N. Engl. J. Med. 2020, 382, e31. [CrossRef]

46. Korhonen, J.; Granberg, B. Sweden Backcasting, Now?-Strategic Planning for Covid-19 Mitigation in a Liberal Democracy. Sustainability 2020, 12, 4138. [CrossRef]

47. Undela, K.; Gudi, S.K. Assumptions for disparities in case-fatality rates of coronavirus disease (COVID-19) across the globe. Eur. Rev. Med. Pharmacol. Sci. 2020, 24, 5180-5182. [CrossRef] [PubMed]

48. Musinguzi, G.; Asamoah, B.O. The Science of Social Distancing and Total Lock Down: Does it Work? Whom does it Benefit? Electron. J. Gen. Med. 2020, 17, 17-19. [CrossRef]

49. Hosseini, S.E. An outlook on the global development of renewable and sustainable energy at the time of COVID-19. Energy Res. Soc. Sci. 2020, 68, 101633. [CrossRef] [PubMed] 
50. Steffen, B.; Egli, F.; Pahle, M.; Schmidt, T.S. Navigating the Clean Energy Transition in the COVID-19 Crisis. Joule 2020, 47, 1-5. [CrossRef]

51. Rosenbloom, D.; Markard, J. A COVID-19 recovery for climate. Science (80-) 2020, 368, 447. [CrossRef]

52. Smith, D.C. COVID-19 and the energy and natural resources sectors: Little room for error. J. Energy Nat. Res. Law 2020, 38, 125-129. [CrossRef]

53. International Energy Agency (IEA). Put Clean Energy at the Heart of Stimulus Plans to Counter the Coronavirus Crisis. 2020. Available online: https://www.iea.org/commentaries/put-clean-energy-at-theheart-of-stimulus-plans-to-counter-the-coronavirus-crisis (accessed on 15 June 2020).

54. Graff, M.; Carley, S. COVID-19 assistance needs to target energy insecurity. Nat. Energy 2020, 5, 352-354. [CrossRef]

55. CarbonTracker. COVID-19 and the Energy Transition: Crisis as Midwife to the New 2020. Available online: https://carbontracker.org/covid-19-and-the-energy-transition/ (accessed on 15 June 2020).

56. Power_Technology. Covid-19 Response Accelerates the Renewable Transition, According to Wärtsilä. 2020. Available online: https://www.power-technology.com/news/covid-19-response-accelerates-the-renewabletransition-according-to-wartsila/ (accessed on 15 June 2020).

57. Roston, E.; Rathi, A.; Biggest Fall in Global Emissions Shows the Limits of Individual Action. Bloomberg Green. 2020. Available online: https://www.bloomberg.com/news/articles/2020-05-19/how-has-covid-19affected-climate-change-co-emissions (accessed on 11 June 2020).

58. United Nations Environment Program (UNEP). Emissions Gap Report. 2019. Available online: https: //wedocs.unep.org/bitstream/handle/20.500.11822/30797/EGR2019.pdf (accessed on 11 June 2020).

59. Seposo, X.; Ueda, K.; Sugata, S.; Yoshino, A.; Takami, A. Short-term effects of air pollution on daily singleand co-morbidity cardiorespiratory outpatient visits. Sci. Total Environ. 2020, 729, 138934. [CrossRef]

60. Rogelj, J.; Shindell, D.; Jiang, K.; Fifita, S. IPCC Report: Mitigation Pathways Compatible with $1.5^{\circ} \mathrm{C}$ in the Context of Sustainable Development; Chapter 2, Glob Warm $15^{\circ} \mathrm{C}$ An IPCC Spec Rep; IPCC: Geneva, Switzerland, 2018.

61. Van Vuuren, D.P.; Stehfest, E.; Gernaat, D.E.H.J.; Van Den Berg, M.; Bijl, D.L.; De Boer, H.S.; Daioglou, V.; Doelman, J.C.; Edelenbosch, Y.O.; Harmsen, M.; et al. Alternative pathways to the $1.5^{\circ} \mathrm{C}$ target reduce the need for negative emission technologies. Nat. Clim. Chang. 2018, 8, 391-397. [CrossRef]

62. Van Barneveld, K.; Quinlan, M.; Kriesler, P.; Junor, A.; Baum, F.; Chowdhury, A.; Junankar, P.N.; Clibborn, S.; Flanagan, F.; Wright, C.F.; et al. The COVID-19 pandemic: Lessons on building more equal and sustainable societies. Econ. Labour. Relat. Rev. 2020, 31, 133-157. [CrossRef]

63. United Nations (UN). Sustainable Development Goals. 2019. Available online: https:// sustainabledevelopment.un.org/sdgs (accessed on 10 June 2020).

64. Chapman, A.; Shigetomi, Y. Developing national frameworks for inclusive sustainable development incorporating lifestyle factor importance. J. Clean Prod. 2018, 200, 39-47. [CrossRef]

65. Sustainable Development Solutions Network. Sustainable Development Report Dashboards. 2019. Available online: https://dashboards.sdgindex.org/ (accessed on 19 June 2020).

(C) 2020 by the authors. Licensee MDPI, Basel, Switzerland. This article is an open access article distributed under the terms and conditions of the Creative Commons Attribution (CC BY) license (http://creativecommons.org/licenses/by/4.0/). 